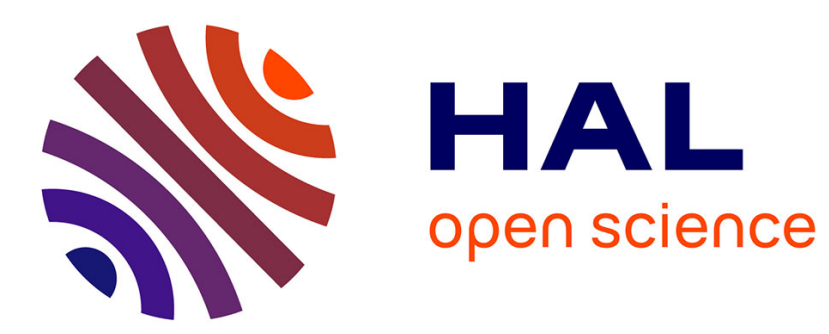

\title{
Building Entrepreneurial Capacity in Post-Communist Poland: A Case Study
}

Barbara Despiney

\section{To cite this version:}

Barbara Despiney. Building Entrepreneurial Capacity in Post-Communist Poland: A Case Study. Human Factors and Ergonomics in Manufacturing and Service Industries, 2005, 15 (1), pp.109-126. 10.1002/hfm.20018 . halshs-00266964

\section{HAL Id: halshs-00266964 https://shs.hal.science/halshs-00266964}

Submitted on 26 Mar 2008

HAL is a multi-disciplinary open access archive for the deposit and dissemination of scientific research documents, whether they are published or not. The documents may come from teaching and research institutions in France or abroad, or from public or private research centers.
L'archive ouverte pluridisciplinaire HAL, est destinée au dépôt et à la diffusion de documents scientifiques de niveau recherche, publiés ou non, émanant des établissements d'enseignement et de recherche français ou étrangers, des laboratoires publics ou privés. 


\title{
Building Entrepreneurial Capacity in Post-Communist Poland: A Case Study
}

\author{
Barbara A. Despiney, Ph.D., in Charge of Research in Institute on Transition \\ and Development Economics/CNRS.
}

\begin{abstract}
"When an industry has chosen a locality for itself it is likely to stay there long: so great are the advantages which people following the same skilled trade get from near neighbourhood to one another", Alfred Marshall, Principles of Economics, Macmillan, London, 1920, p.271
\end{abstract}

\begin{abstract}
Process of globalisation defines the new frontiers, leaving more importance to the territory. In the context of a rapidly changing international environment it is of no small importance to ask some question about the present situation in the bordering regions, their foreseeable evolution, both short- and long-term, and the economic and social consequences liable to results, considering their geographical and demographic situation, and their structures of activity. The redrawing of old national territories no longer seems to be the product of diplomacy and, in particular, wars; henceforth, it would appear to depend upon industrial economics. This is especially significant in the case of "Neisse" Euroregion located on PolishCzech-German borders. Here are, at the present time, the chances of reviving a localized productive system that would give life to new forms of interregional co-operation. The aim of this article is to offer a reflection on the relevance of the marshallian district concept in the analysis of this interregional co-operation. The marshallian industrial district is based on the external economies of agglomerations and the economics of urbanisation, and this kind of development we can see today in Poland. The study of localized productive systems must be thorough and multidisciplinary and carried out through fieldwork. The aim is to understand how work, relationships and culture as well as material and immaterial infrastructures that give a place its original identity within the international division of labour regenerate in locally coherent forms. Regional production system grouped together on spatial level and integrated company networks at the regional level could serve to create local hubs of competition in Central and Eastern Europe.
\end{abstract}

Key words: globalisation, transition, cross border co-operation.

JEL Classification : B3, R12, P2.

Contact informations :

106-112, Boulevard de l'Hôpital, 75647 PARIS CEDEX 13, France

E-mai: despiney@univ-paris1.fr;tel.33 144078188 , fax 33144078191 


\section{Introduction.}

The level of entrepreneurial activity (as defined as a new business venture, selfemployment or the expansion of an existing business) varies markedly between countries. New enterprises play an important role in the creation of jobs.

I. Besides, the globalisation process defines the new frontiers, leaving more importance to the territory. A more "territorial" development model has been put forward since the 1970's (its origin is based, among other things, on the notions of fundamental needs, eco-development and self-centred development) (AYDALOT, 1985). Today more than ever, the development paradigm breaks with the functional ideas concerning the organisation of economic life and suggests a return to a "territorial" vision, particularly in light of the transition economies' example. In the context of a rapidly changing international environment it is of no small importance to ask some question about the present situation in the bordering regions, their foreseeable evolution, both short- and long-term, and the economic and social consequences liable to results, considering their geographical and demographic situation, and their structures of activity. The redrawing of old national territories no longer seems to be the product of diplomacy and, in particular, wars; henceforth, it would appear to depend upon industrial economics (MICHALET, 2000). This is especially significant in the case of "Neisse" Euroregion located on Polish-Czech-German borders. Here are, at the present time, the chances of reviving a localized productive system (cluster) that would give life to new forms of interregional co-operation. Entrepreneurs are a critical element in the formation of clusters and their actions are important to revitalize and transform local economies.

\section{Building Entrepreneurial Capacity in Poland.}

The observation of the Polish economy in transition points to two phenomena:

$1 /$ the emergence of small and medium-sized companies acting as a motor for growth and job creation, this emergence being spatially determined; 
2/ the overthrowing of old spatial hierarchies; the regions endowed with heavy industries which, traditionally, enjoyed a relatively large share of growth, are now in a recession phase, while other regions show signs of dynamism, like for example, bordering regions.

Recent growth in Poland is closely linked to the dynamism of small and medium-sized emerging structures of a spontaneous nature.

Two processes are fondamental in entrepreneurship building in Central and Eastern Europe: privatization and decentralization.

\section{I.1. Privatization.}

In the Soviet development model, state's heavy industry was at the heart of all development, today a vital element of the transformation process in Poland is privatization of the economy, coupled with the division of large state enterprises into smaller independent units.

Privatization helps to enlarge the class of entrepreneurs and has led to structural changes in the economy. In fact, recent growth in Poland is closely linked to the dynamism of small and medium-sized emerging structures of a spontaneous nature. Brunat refers to diffuse industrialisation, wherein the essentially familial relationship can be considered an informal type of relationship (BRUNAT, 1995). In the space of ten years, between 1988 (the year the law concerning the liberalisation of economic activity came into effect) and 1998, the numbers of entrepreneurs grew from 700000 to 1600 000. Estimates carried out for the year 1990 alone refer to the creation of 140000 , of which the majority (126 000) ceased to exist, leaving the total number of existing firms at 518000 at the end of the year (SURDEJ, 2000). In spite of a slight slowdown between 1993 and 1995, micro-firms represent a very dynamic demographic process; the number of active micro-firms has been increasing by around 200 000 a year, on average, since 1996. First important decrease (50 000) was noted in 2001, linked to recent Polish economic and budget crisis. There are 65 small and medium-sized 
firms for every 1000 inhabitants in Poland, as opposed to 51 in the European Union. In fact, the policy aimed at encouraging the development of small, private production and foreign companies does not date from the change of the political regime. In 1976 Gierek's communist government introduced the low about "Polonias" small joint-ventures. But, the emergence of small and medium-sized industries and firms has been particularly visible since the beginning of transition (CHMIEL, 1997; GRUDZEWSKI \& HEJDUK, 1998; DUCHENE \& RUSIN, 2002). Small, private, spontaneously grown activities are the foundation stones of the Polish economic revival. The country's economic history and the capitalist culture that make up the national heritage have helped to establish a new commercial and entrepreneurial spirit in western Poland in particular. Although the majority of small and medium-sized industries and firms were created in the commercial sector, new entrepreneurs are now beginning to orient capital accumulated in this sector towards manufacturing. This sector has a great potential for creating new jobs. In 2000 65,5\% of all employment was in this sector (in 1997 it was $61,1 \%$ ). Small and medium-size enterprises constitute the main source of employment for those who had lost jobs in the state sector, mostly in industry (PUCHALA, 2002).

\section{Table 1 here}

In fact, the emergence of small and medium-sized companies acting as a motor for growth and job creation, this emergence being spatially determined: near German, Czech and Baltic borders (DESPINEY\&BACZKO, 2001). The level of economic activity can bee mesured by number of active SMEs in new voivodships (see Table 2):

\section{Table 2 here}

Without Mazovia, which has it's position thanks to Warsaw and the suburbs, both Silesias (Upper and Lower), Great and Little Poland are in the best position in the field of entrepreneurship building in Poland. 
The rapid dissemination is important matter for the efficiency of the economic growth. For Paul Krugman there are two important activities for trade development and economic growth: innovation and technology transfer (KRUGMAN, 1979). But even growth in the industrialized countries is highly dependent on the effectiveness with which they can adopt new technology from sources foreign and domestic. The invention was quite abundant in former Soviet Union, but what was missing was innovation, that is, the dissemination and widespread utilization of the innovation (DESPINEY-ZOCHOWSKA, 1982; SCHNEIDER, 2000). In this situation the technology transfer was considered the only remedy for underdevelopment. This phenomenon can be explain by different behaviour of entrepreneurs in former socialistes countries which was totally different from capitalistic behaviour (BAUMOL, 2002). The market mechanism forces firms to devote a steady stream of expenditure to innovative activities. Also is necessary to stress another institutional attributes like secure private property to encourage saving and investment, secure right of personal liberty, and enforced right of contract, as well as stable, honest and responsive government (quoted in BAUMOL, 2002). Duchêne and Rusin argue that, innovation in Polish transition is seen as a complex socio-economic and organisational process, more then technical progress. More precisely they look at the reallocation from industrial employment to small entrepreneurial activities as a potential start up of transitional growth (DUCHENE\&RUSIN\&TURLEA, 2002).

The internalisation and rutinisation in the face of the uncertainty and complexity of the innovative process also point to the importance of particular organisational arrangements for the success or failure of individual innovative attempts (DOSI, 2000).

\section{I.2.Decentralization.}

Entrepreneurship is inherently a local phenomenon (FELDMAN\&FRANCIS, 2001). In Poland very positive influence on local entrepreneurship and development has had the 
reform of local administration. The decentralisation process did not start with the transition, the same may be said of the economic decentralisation process (ANDREFF, 1987; DESPINEY-ZOCHOWSKA, 1988,). Localised productive systems can be an instrument for territorial development policies. With the appearance of LPS, there has been a movement towards a new system of dialogue between the State (i.e. the fifteen members of the European Union) and local communities (COURLET, 2000). The industrial districts analysis used in Italy points to the first elements of local governance on this territory through the decisions of local government authorities, the private sector and civil society (REQUIER-DESJARDIN, 2001). The regions need autonomy, power and the capability to carry out theirs own policies, all of which depend on territorial decentralisation. In Poland and the Czech Republic, state territorial structures are now being decentralised, we must, thus, ask ourselves how the territorial element can help to orient this evolution towards improved productive organisation and entrepreneurship.

\section{I.2.1. The reforms before Transition.}

The relations between the Centre and the enterprises were affected by introduction of some indirect control mechanisms (prices and taxation), during implementation of the 1982 economic reform (ROGULSKA, 1985). In order to perfect the organisation and the functioning of the central and local administrations, new steps were taken as early as 1983 . On July $20^{\text {th }}, 1983$, the provisions for the reform of local powers in Poland were lain out in a law concerning the People's Council and territorial autonomy. A series of texts concerning socio-economic planning in the country as well as the new 1984 budget confirmed this new organisation of administrative life in Poland. These legal measures served to reinforce the role of territorial organs while forming the basis for their legal jurisdiction. By transmitting almost all the concerns of local and regional interest to the organs of the territorial power 
(such as industry, agriculture and services, as well as social and community infrastructure), the 1983 law drew a new outline for the local economy. This law also gave these organs the jurisdiction to create firms on the local level, and in 1983 alone, 3000 State companies previously managed by the central organs were placed under the control of local powers. The new law recognised the financial autonomy of the People's Councils and defined three types of budget resources for them: 1) their "own" income (taxes), 2) endowments allocated to specific, well-defined projects, 3) "general" endowments (this was an innovation in Poland at the time; fixed for a five-year period, these funds could be used freely.) This reform of the public administration was followed by a second series of legal acts voted by the Diet on October $23^{\text {rd }}, 1987$ (DESPINEY-ZOCHOWSKA, 1988).

\section{I.2.2. The reforms after 1989 .}

On March $20^{\text {th }}, 1990$, the desire to continue the decentralisation process that had been started in the 1980 's led to a law concerning territorial self-administration: Local self-government Act (World Bank, 1992). This new reform abolished several monopolies: that of the single Party as the sole source of power, that of State administration (over 100000 civil servants were transferred to local communities), that of State ownership and, lastly, that of a single centralised tax system. Today, local communities can manage their own finances independently, working from their own budget. Starting January $1^{\text {st }}, 1994$, the new system for financing municipalities entered into effect (based on a law passed December $10^{\text {th }}, 1993$ ). It stipulated, among other things, that primary schools would return under municipal administration, who, in turn, were subordinated to the national Ministry of Education according to a law dated May 17, 1990. Faced with the weakness of the voüvodes which led to a fall in their autonomy, a new reform concerning territorial administration was introduced in January 1999, re-establishing the intermediate level of power, the powiat, (a sort of canton or district). This new administrative reform has resulted in the reduction of the number of 
voüvodship from 49 to 16; there are 308 powiats and 65 city-powiats. The reform was preceded by a new reform of the Centre on October $1^{\text {st }}, 1996$, reinforcing the Prime minister's role and defining new powers for the voüvodes. This reform created, among other things, a Committee for European Integration. The new administrative outline aimed, among other things, to facilitate the establishment of a regional administration capable of managing the Structural Funds that Poland is expected to receive after joining the European Union (DESPINEY-ZOCHOWSKA, 1999). It should also allow the country to join the Europe of the regions, even if the latter is emerging with difficulty.

\section{Cross-border Cooperation.}

Poland carries out trans-border and euro-regional cooperation with all its neighbour countries. Participants in the cooperation number 588 Polish communities, that is, one of four in the country. The appropriate legal framework for cross-border co-operation (CBC) on Polish borders has been particularly important. Poland signed the Convention of Madrid and the European Charter of Territorial Self-management in January 1993, which the President ratified in March that same year. The action cleared the legal status of foreign activity for Polish local and regional authorities, including those located near the borders by unambiguously authorising foreign contacts, and implementing Western European standards for co-operation. $\mathrm{CBC}$ should be regarded as a specific form of international regional cooperation, whose territorial scope and subject ranges are, to a great extent, shaped by political factors. On the other hand, its development prospects are determined by impartial socioeconomic, technological, institutional and geographical condition existent on both sides of the border, as well as certain factors of more general character - chiefly the conditions brought about by the process of integration in Europe. The latter means that, at the moment, regional $\mathrm{CBC}$ should be regarded as a transitional phase, as we assume, that Poland, like the Czech Republic, Slovakia and Hungary, will enter the EU which practically means incorporating 
these countries into the uniform economic system of Europe and cancelling borders in the traditional sense of the word. However, the continuation of the previously concluded CBC will remain an issue, particularly in the form of euroregions, since political decisions to remove borders do not mean automatic liquidation of historical bygones and differences in the sphere of social and economic life

\section{II.1.Euro-regions Map.}

In 2001, ten Euro-regions operated along Polish borders and twelve kinds of crossborder accords such as unions, associations, etc. The following is a list of the major one (STARZYK, 1996):

1. Euroregion "Neisse - Nisa-Nysa" (December 1991),

2. Euroregion "Sprewa - Nysa - Bóbr" (September 1993),

3. Euroregion “Pro Europe Viadrina” (December 1993),

4. Euroregion "Pomerania" (December 1995),

5. Bilateral Protected Area of the Lower Oder Valley (May 1992),

- Transborder Accords in the region of the Sudetes,

6. Transborder "Black Triangle" Area (June 1991),

7. Bilateral Peat Reservation "Izer" (under organisation),

8. Bilateral Reserve of Biosphere Karkonosze/Krkonoše (November 1992),

9. Euroregion "Glacensis" (December 1996),

- $\rightarrow$ Transborder Accords in the region of Silesia and the Carpathians,

10. Transborder region "Silesia-Moravia" (September 1992),

11. Transborder region of "Cieszyn Silesia" (March 1993), 
12. Transborder region of the Żywiec Beskides (June 1992),

13. Euroregion "the Tatra" (August 1994),

14. The "Tatra" International Reserve of Biosphere (November 1992),

15. Transborder Region of the Sącz Beskides (under organisation),

16. Euroregion the "Carpathians" (February 1993),

17. The "Eastern Carpathians" International Reserve of Biosphere (June 1991),

18. The "Bug" Euroregion (September 1995),

19. Polish - Belarussian transborder area (April 1995),

20. Transborder Region of "Green Lungs of Europe",

21. The Transborder Position of the World Humanity Heritage (1992) prospects for the establishment of the Bilateral Biosphere Reserve of "Puszcza Białowieska" (The Białowieża Wilderness),

22. The River Niemen Euroregion (June 1997),

23. „Baltic” Euroregion ( February 1998)

\section{Figure 1 here}

There exist in Poland, at the country's western border, four Euroregions: "Pomerania", "Pro-Europa Viadrina", Szprewa-Nysa-Bobr" and "Neisse. In order to study the emergence of entrepreneurial capacity in the condition of globalisation precess we have concentrated on the case of the "Neisse" Euroregion, situated at the Polish-German-Czech border, which presents an inherited historical and regional continuity enabling us to observe the features that make up regional dynamism. In our work carried out for the DATAR in 1996, the border is, in fact, presented as providing a strong growth potential (SAMSON et al, 1996). This work pointed out emergence of a dynamic peripheral crown in the western and southern part of the country, 
along the German and Czech borders. This growth should be of the European Alpine sort, based not only on economies of agglomeration, but also on industrial and tertiary activities linked to tourist activities. The country's economic history and the capitalist culture that make up the national heritage have helped to establish a new commercial and entrepreneurial spirit in Poland more then in another eastern european countries, Russia in particular. The Polish latest researches confirm this phenomenon (GRUCHMAN et al, 1988; PAEP-Report, 2001; DESPINEY\&BACZKO, 2001).

\section{II.2. Building Entrepreneurial Capacity in 'Neisse Euroregion”.}

The "Neisse" Euroregion was created in december 1991 and is made up of 6 Saxon districts (Bautzen, Kamenz, Löbau-Zittau, Oberlausitz, Görlitz and Hoyerswerda), 44 gminas of the Lower Silesia voïvodship, 4 gminas belonging to the Lubuskie voïvodship and the Czech administrative units of Liberec, Jablonec, Semily, Ceska Lipa as well as the Sluknov region (see Figure 2). The new administrative divide in Poland, introduced the $1^{\text {st }}$ of January 1999 make three countries comparison and co-operation possible (DESPINEYZOCHOWSKA, 1999).

Initially a flourishing economic region, the area groups together Lower Silesia, Northern Bohemia and Upper Lusace and counts nearly 1.5 million inhabitants (725 800 in the German part alone). The "Neisse" Euroregion, one among four created along the Oder-Neisse border, is considered a laboratory for other initiatives of this type (for example, in the field of statistics, generally held as very unreliable during the transition period). The Polish part of Euroregion is part of a statistical programme entitled "PL-14 Euroregions", elaborated by the Jelenia Gora Statistics Office and integrated into the GUS's foreign co-operation programme. At present, this programme is accepted in the Eurostat framework by the European Union.

Figure 2 here 


\section{II.2.1. Regional trajectory.}

A long-term vision alone makes it possible to analyse a territory's dynamics, based on the observation of men and their relationships among themselves and with institutions. In the context of our hypothesis concerning the possible revival of LPS in the "Neisse" Euroregion, we find ourselves faced with the heritage of historic and regional continuity. Silesia's economic development made it a remarkably advanced region in spite of its social order's feudal structures. Central Europe's integration with the international economic system was achieved mainly through German channels. The economic and cultural links between Saxony, Polish Silesia and Czech Bohemia are the legacy of the shared history of three countries with a common border, based more particularly on the German presence in these regions over the centuries (JEANNIN, 1991). The fabric industry experienced a period of development in the XVIth century, initiated by merchants from Upper Germany. The health of the textile sector also had an impact on sales of drapery. Silesia, Saxony and Bohemia sold massive amounts of fairly poor quality, but inexpensive, wool fabrics in the East until the middle of the XVIIth century. From the beginning of the XVIIth century, villages began to take on the overflow of weaving and by the XVIIIth century, entire families were involved in this work, along with spinning. The impetus came from urban centres such as Hirschberg (today known as Jelenia Gora) whose wealthy entrepreneurs set them apart. The positive knock-on effects created by rural industry - job creation, the stimulation of demographic growth, the activation of the domestic food market - were reinforced by the fact that the manufacturing of fabrics took place within a region rich in a number of industries. Economic development in Silesia made this province remarkably advanced in spite of the feudal infrastructure controlling society (HENDRERSON, 1954). This appreciation is based above all on the international importance of the fabric producers, who rivalled the French on the Spanish and American markets. The structural crisis in the old mining economy that took place in the XVIth century encouraged 
the appearance of dye producers in Silesia and the seeds of the future chemical industry. The existance of adwanced industrial civilization here, with a long history of linkages between science and technology, had a huge influence on economic development of central european countries. But, at the time, European industrial geography was characterised by the dispersion of its industries, with pockets of industry sunk into the rural landscape (VELTZ, 1996). Industrial growth during the second half of the XIXth century and the start of the XXth century is characterised by a concentration in the new industrial regions in the North, but also - and above all else - by its polarisation around large agglomerations which become big production centres.

\section{2.2. The split 1945-1989.}

Before the Second World War, Silesia could be considered an industrial district in the Marshallian sense of the term (MARSHALL, 1920). The term "localized productive system", "industrial district" or "cluster" designates a collective way of living, thinking and producing that is characteristic of a given society, a space, and milieu. It is a socio-territorial entity characterised by the presence of an active community of people and a population of companies in a given geographical space. The industrial district is governed by a set of community and religious values or corporatist practices. Large proportions of the industrial workforce were employed in the regions situated East of the Oder and Neisse, which, at the time, were still German ( $43 \%$ of the hemp industry workforce, $49 \%$ of the spinning workforce, and $48 \%$ of the linen industry) (LEPESANT, 1997). The 1945 border changes and the expulsion of the Germans put an end to the homogeneity of the local productive system in Saxony, Lower Silesia and Bohemia. During the communist period, the OderNeisse line could be thought of as a "split" or "cut", as Claude Courlet wrote, producing total discontinuity in the industrial district's trajectory (COURLET, 1988). On either side of the Oder-Neisse border, the massive population migrations that took place after the Second 
World War meant that many people had difficulty identifying with these border regions. Indeed, the surge of refugees from the East and the migrations following the war modified the population structure on either side of the Oder-Neisse, undermining the likelihood of seeing specific cultures emerge and stopping the revival of regional traditions. The German regions being studied were made up of the lands of the former Junkers expropriated following the agrarian reform of 1945 which led to the formation of large collective holdings (LACQUEMENT, 1993). On the Polish side, formerly German lands became Polish, before their rapid confiscation and collectivisation (DESPINEY-ZOCHOWSKA, 1995). The workers who came from Polish lands in the East had no rural tradition and their integration created a number of problems for the authorities throughout the communist period. On the German side, the limited number of family exploitations was also linked to the absence of rural traditions sufficiently well anchored in the local community. It was in this area that a number of ethnic German communities from Central Europe were transplanted (BAFOIL, 1995). Between 1945 and 1989, the East German, Polish and Czechoslovak authorities failed to put into place a common development policy in the border lands with the exception of the 1970's. In the industrial field, few new industries were created and an intensive exploitation of the coal basin can be noted in both parts of the region: Lusatia in the GDR and the Turoszow region in Poland. During the Communist period there was a strong development of the textile industry, but this took place in isolation in each of the three bordering countries (BAFOIL, 1995). These border regions are fragile in large part due to an all too similar industrial structure on either side of the Oder-Neisse border. In Germany, the Länder soon disappeared, only to be replaced by smaller Kreise soon to be reduced to nothing more than implementation centres for decisions made at the central level. In Poland, Gierek carried out opposite policy in 1975 , liquidating the powiat - the intermediate administrative level - and introducing 49 voïvodhips. 


\section{Transition 1989-2002.}

The Euroregion, whose economic components are not complementary; on the contrary, their structures are largely identical, is a legacy of the communist economic system's logic. In Central Europe, the textiles and clothing sector shows a big number of unfavourable factors. In Eastern Germany, from January 1994 it was the European RETEX programme that was to bring massive aid to the East German textile industry. The restructuring of textile and clothing was part of a programme of complete overhall of Saxony's economic structure (ATLAS), without calling into question the region's industrial identity. At the Polish border the economic development project was "Perlenkette entlang der Neisse" a concerted development policy scheme planned for Upper Lusatia. The transition process in former GDR, was not spontaneous and maintenance of economic activities depended on massive financial transfers and an active role by the German State. This example of industrial restructuring is highly instructive in that it has enabled the regions to preserve their industrial centres. The Polish case is completely different. In Poland, the textile industry belongs to that branch of the Polish economy which suffered much from the shock therapy introduced by Leszek Balcerowicz's programme on 1 January 1990 (LIPOWSKI\&DESPINEY, 1991). The majority of small and medium-sized industries and firms were created at the beginning of transition, with almost no help from the State. German enterprises have adopted a strategy based on outward-processing trade (OPT) witch Polish and Czech partners in order to improve international competitiveness. In the specific case of subcontracting, we find ourselves in the presence of star-shaped relationships between firms, in other words, the relationships between players work two by two (COURLET \& PECQUEUR, 1991). There are no horizontal relationships between partners in the same firm and this type of relationship can often create a form of dependence for small and medium-sized firms. Hence, the danger for the revival of the local productive system; the eventual disappearance of local production units' 
independence and their transformation into subcontracting entities for larger firms looking for the necessary technical know-how, inexpensive labour and a pre-existing client network. Subcontracting certainly reinforced the competitive nature of the Polish and Czech textile industry, particularly in the clothing sector. Not only did made-to-order contracts help a number a producers to better use their production capacities, but Polish companies also benefited from technological transfers from German companies (DREE, 1998). Nevertheless, subcontracted finishing stage work held certain disadvantages; for instance, it further reduced outlets for intermediate products which were provided by the German placing the orders. It has yet to be seen, to what extent Polish and Czech textile and clothing firms in the region have suffered from this form of production. The contribution of new flexible methods of production to local development and to the dynamics of regional integration is not as disappointing as often suggested (PELLEGRIN, 1999).

\section{III.1. Building regional identity.}

The border is now, thus, a "seam" in a contact zone, a place of competition and complementarity (COURLET, 1988). The question remains whether or not "local industrial culture" (a key element in the institutional framework of any local productive system based on local industrial tradition) was destroyed by forty-five year split linked up with communism and to what extent the socialist heritage weighs on the area's structure (German, Polish and Czech) and on the reorganisation of relationships between organisations implanted in the area. The incomplete market and institutional reforms in especially in three studied countries contribute to hight level of risk in transborder economic relationships (KRÄTKE,1997). But, we may expect that the return to the culture of capitalism in those three parts of the Euroregion will be easier than in other former socialist countries, especially Russia. Cultural change under impact of economic change has been argued by Alfred Marshall more than a century ago (MARSHALL, 1920). Marshall understood that customs making a part of what 
economists call today informal rules, are not immutable but "have been imperceptibly growing and dwindling again, to meet the changing exigencies of successive generations" (quoted in WINIECKI, 1998). He strongly emphasized the part played by human factors in his work, pointing out "mental and moral "qualities, such as integrity, self-confidence, patience temperance, honesty, loyalty, etc., (ARENA, 2000). The local productive system creates an "industrial atmosphere", factor of osmosis and the transmission of know how over time. Its most noticeable characteristic is its relatively homogeneous system of values and thought, which may be seen as the expression of a certain system of ethics concerning work, activity, family and reciprocity, all of which may be seen to condition the main aspects of life (BECCATINI, 1992). It has its own specific forms of know-how, that are inimitable and deeply anchored in the territory (specific and general purpose artisan know-how).

Since the beginning of transition, the role of the Oder-Neisse border has made an about-face; the ease with which it can be crossed makes contact possible and this has led to the development of trade, migrations and even conflicts (BAFOIL, 1995). The percentage of the population born in a area and still residing in the same place as adults can be used as a demographic parameter indicating the degree of historic attachment. This parameter also indicates the size of migrations following the Second World War, as well as those linked to the development of large industrial centres, this being accompanied by the creation of large urban centres (SZLACHCICOWA, 1999). The type of relationship the respondents have with their place of residence may also constitute a parameter of regional identity: how is the state of the region and the community perceived, how much attention should be paid to the responsibility and the attitude of inhabitants towards their place of residence. As far as the regional identity of the Czech population is concerned, the percentage of the population now living in the region near the German border that was already there before the war represents 10 to $15 \%$ of the present population. The majority of the population arrived relatively 
recently, following the expulsion of the Sudeten Germans. Based on the 1991 census, all the Czech border regions show below average values for the percentage of the population born in the area of residence, (the national average being $49.9 \%)(\mathrm{ZICH}, 1997)$. The same may be said of the Czech population living in the "Neisse" Euroregion. Thus, the percentages of inhabitants still living in the area where they were born are as follows: $48.9 \%$ in Semily, $44.9 \%$ in Liberec, $42.6 \%$ in Jablonec, $42.3 \%$ in Decin and $32.3 \%$ in Ceska Lipa. It also seems probable that these populations have less in common with the location, the region and its history. The results of a sociological study of the population living in the border regions offer a clear answer to these questions (ZICH, 1997). Based on the answers given to the question asking the individuals surveyed whether or not they are comfortable in the place where they are living, we may conclude that in the majority of cases, the relationship with the location is a very positive one. The people surveyed judge their relationship with their place of residence to be either positive or very positive. The structure of the answers shows that the attitude towards the region is positive but also that the people questioned like their region and know it well, although there is little interest in local problems. The difference in the answers provided by the various groups is not particularly significant. Involvement and work in local activities is in line with the national average in the Czech Republic. The population surveyed in the border regions showed signs of great stability in the answers they gave to other questions. Only $3.5 \%$ said they were planning on moving in the short term, $76.6 \%$ declared they were not planning on moving and $19.5 \%$ said they planned on moving one day. As far as the districts belonging to the "Neisse" Euroregion are concerned, Decin, Ceska Lipa and Liberec (the Semily district was not surveyed) only $5 \%$ of people surveyed declared that they would like to leave as soon as possible, $18 \%$ more said they might leave at some point and $77 \%$ did not plan on moving elsewhere. Among those who plan on leaving or hope to leave, $33 \%$ want to move to another place but plan on remaining near the border. A relatively small percentage 
of the inhabitants of the border regions plans on changing its place of residence and an even smaller percentage has already decided to leave. The reasons given for these moves are rational: the leading reason is the poor state of the environment in northern Bohemia. The other reasons given by potential migrants are not substantially different from answers given in the rest of the country. The difficult situation on the labour market since 1994 (date of the survey) - mainly in the districts of Northern Bohemia - certainly had a negative impact on the population's stability. The situation in small cities has worsened the fastest, with the contraction or the complete liquidation of agricultural production, accompanied by transport problems. These problems mainly concern the northern part of Decin. In spite of the problems encountered on the labour market, the Czech population along the German border shows great stability and a positive attitude towards its place of residence. The main reasons given for any future emigration are reasons relating to the poor state of the environment, personal problems or employment-related reasons. There is no sign of politically or nationally motivated migrations (with the exception of recent requests made by the gypsies) (ZICH, 1997).

Numerous surveys carried out among the Polish and German residents show that residents of Polish border area demonstrate a stronger feeling of regional unity. Unlike the case in the Czech and Polish parts, a noticeable fall in the population has taken place in the German part of Euroregion, with a tendency for young people to leave. The departure of young people has been particularly marked in eastern Saxony (GOLDHAN, 1997). This population drain reflects the region's decline, with uneven development across the region that cannot be blamed solely on its distance from the centre of the country, but also on the former choices of the GDR, implementing sectorial development, and localising industry mainly in large urban centres (GRABHER, 1994). The critical situation caused unemployment and high levels of emigration, particularly among the young, creating, in turn, an aging population. 
More so since reunification than at the time of the GDR, eastern Saxony is on the outskirts of activity. Studies carried out by the Institute of Geography in Leipzig show that given eastern Saxony's many handicaps, this space runs the risk of being the seat of considerable disparities. This can be seen in the increasing attention to Bautzen (Budziszyn), the capital of Upper Lusatia in its central position, compared with Görlitz which fell in to a peripheral position after 1945 (see Table 3). Today, only $37 \%$ of population is ready to stay in the city and $63 \%$ would like to leave.

\section{Table 3 here}

Bautzen, seems to be in better position because the slavonic and catholic origin of the population ( Europa regional, 1/1996, p.21). Individuals with common cultural backgrounds and experiences will share reasonably convergent mental models, ideologies, and institutions (DENZAU\&NORTH, 1994). The system of value judgements incorporated into European culture was developed in a general framework in which Chistianity played an important role (KUKLINSKI, 2002). Will Christianity assume a higher level of unity between catholics, protestants and orthodox in order to built new European identity?

\section{III.2. Local initiatives: Kamienna Gora Special Economic Zone for Medium Business and Textile Euroregion.}

According Feldman and Francis, individual entrepreneurs are in the best position to move technology, the industry and the region forward, but, this is not to say that there is no role for local government policy in promoting entrepreneurship (FELDMAN\&FRANCIS, 2001). Legal and tax framework, research institutions and social relationships are definitely areas for innovation and entrepreneurship. The new spatial dynamics appear in link with innovation: the concept of "milieu innovateur" (MAILLAT 1988, PERRIN, 1989). According to GREMI (Groupe de Recherche Europeen sur les Milieu Innovateur - European Research Group on Innovative Areas has been based in Paris since 1984 with the help of the 
Ministry of Urbanisation and Housing), Fordism opened the way to the new "territorial" type of development, based on an innovative capacity that is better able to carry out projects within social and industrial networks on a local level. Will the two processes, i.e. decentralisation presently underway in the East and the possible revival of LPS in this part of Europe, reinforce one another or follow different dynamics? For the moment it is difficult to answer this question, baring in mind that the process has only just begun. For example, there is no consensus on the role government authorities should play in the birth of LPS. For some, the revival of LPS will only take place with the active support of regional authorities (either owners or simple players) in developing a network of diffuse, non spontaneous industries (SAMSON \& GOUTIN-BOURLAT, 1995). This is the case of the former GDR, where the transition process was not spontaneous and maintenance of economic activities depended on massive financial transfers and an active role by the German State (BOUDIERBENSEEEBA, 2002; NIVET, 2002). The Polish case was completely different in the beginning of the transition The majority of small and medium-sized industries and firms were created at the beginning of transition, with almost no help from the State (CHMIEL, 1997). The Polish experience in the 1990s confirms the little role played by local institutions in the process of entrepreneurship building. But now the situation has been changing with the creation of Special Economic Zone for Medium Business in Kamienna Gora, in september 1998, in Polish part of "Neisse" Euroregion, near border crossing with Germany and the Czech Republic. The idea to create SEZ is relatively new in Poland (DESPINEYZOCHOWSKA, 1998). This project is most promising for a country like Poland having an important transport and transit system. The Kamienna Gora zone situated in "Neisse Euroregion" has made a considerable improvement in this field of entrepreneurship building. But the influence of SEZ on the position of all cities involved in this experience is neither automatic nor immediate. The important problem now is the futur of SEZ, which is under 
discussion beetwen Polish Government and European Commission. The concept of special economic zones has drawn critisism, however, especially with regard to international competition and impact of unequal growth across a national territory. Companies that displayed interest in investing in SEZs received tax breaks: exemptions from corporate tax for the first 10 years, and 50 percent exemptions for following 10 years if the companies meet investment-value and employment conditions. The European Commission was encouraged to treat them as specific subsidies, but in fact, investors which have been invested in Polish special Economic Zones will leave an important part of benefices accorded by Polish autorities. Concern for SMEs invested in Kamienne Gora SEZ the last dispositions maintain their privileges during the first five years and similar exemptions like for big companies after this period.

Another local initiative is the creation of "Textile Euroregion" on Polish-GermanCzech border. The concerted action of the three zones making up the Euroregion is now possible thanks to this new initiative which took place between local German, Polish and Czech authorities. Three major problems will be resolve in near future:

- the lack of a common strategy for the Euroregion's light industry;

- the difficulty in finding credit;

- the lack of accurate information on the situation of the sector's firms.

The first common decision was to save textile industry by built three Associations of producers in textile and clothing. Those three associations of textile and clothing firms are created in order to face Asian competition. The region might specialise in linens: today some manufacturers in the textile and clothing sector have started a new conquest of the ex-URSS markets, less demanding in terms of quality. It would seem that cross-border co-operation ought to allow economies of scale, and cut production costs by half (KOZA, 1994). This 
could compensate for the lack of economies of scale linked to the eastern markets disintegration (ANDREFF, 1994.) 


\section{REFERENCES}

Andreff W., 1994, From dezintegration to new integration in former Soviet Union and Eastern Europe. In Capitalism in the East. A difficult delivery. (Economica, Paris).

Andreff W., 1986, The End of Planned Industrialisation Model: What the lessons for the Third World?, ORSTOM Conference , Paris, 26-27 of February .

Aydalot Ph. ., 1985, Crisis and space. (Economica, Paris).

Boudier-Bensebaa F., 2002, The east German transformation: Between shock therapy and handouts, RECEO, vol.33, $\mathrm{N}^{\circ} 2$.

Arena R., 2000, Economic Institutions and Social organisation in Marshall's work: An evolutionery interpretation, Conference: Organisations and Institutions, Amiens, 25 -26 May.

Bafoil F., 1995, Between memory and expectations: An sociological approach of Neisse Euroregion, In Cahiers du ROSES, $\mathrm{N}^{\circ} 1 / 1995$.

Baumol W.J, 2002, The free-market innovation machine. Analyzing the growth miracle of capitalism, (Princeton University Press, N. Jersey).

Beccatini G., 1992, Marshallien district: A socio-economic notion”, In Les régions qui gagnent. Districts et réseaux: les nouveaux paradigmes de la géographie économique, Benko G. and Lipietz A., (eds),(PUF, Paris).

Brunat E., 1995., Regional Emergence and Territorial Dynamics: essais on Russian and Polish Transition, Thesis, University of Grenoble.

Chmiel J., 1997,.SMS and regional development . In Studia i Prace, ZBSE/GUS, Fasc. 243.

Courlet C., 1988, The frontier: Cut or seving? , In Economie et Humanisme, Fasc. 301.

Courlet C. and Pecquer B.,1992, Localized productif systèmes in France : a new development model? In Les régions qui gagnent. Districts et réseaux: les nouveaux paradigmes de la géographie économique, Benko G. and Lipietz A., (eds.) (PUF, Paris).

Courlet C., 2000, Industriels Districts and Localized Productif Systems in France (DATAR, Paris).

Denzau A. and North D., 1994,"Shared Mental Models: Ideologies and Institutions", Kyklos, Vol.47, Fasc.1,3-31.

Despiney-Zochowska B.A, 1982, Socialist Countries and NIEO. An attitude towards developing countries since 1974, Thesis, University of Paris 1.

Despiney-Zochowska B.A., 1988, The Reform of the Centre. In Le Courrier des Pays de l'Est, Fasc. 332.

Despiney-Zochowska B.A., 1995, Rural restructuring in Oder-Neisse region. In Cahiers $d u$ ROSES, Fasc. 1 .

Despiney-Zochowska B.A.,1998, The Border Effect and New Forms of Territorial Organisation in Poland. In L'organisation du développment territorial dans les pays en transition. Martin C. (ed.) (University of Grenoble).

Despiney-Zochowska B.A, 1997. Industrial restructuring - proximity effects. The case of the "Neisse" Euroregion. In Acta Uniwersitatis Wratislaviensis, Fasc.1941.

Despiney-Zochowska B.A, 1999. Regional Disparities in Poland On the Eve of Joining the European Union. In Le Courrier des Pays de l'Est, Fasc. 437.

Despiney-Zochowska B.A., 2000.Marshallian district - an essais of interpretation of regional development in Poland. In Strategiczne Problemy rozwoju miast i regionow, Jewtuchowicz A., (ed.) (University of Lodz).

Despiney B. and Baczko T., 2001. On first line. In Magazyn Finansowy. Special Issue. 
Dosi G., 2000. Innovation, organization and economics dynamics. Selected essayes. (Edward Elgar, London ).

DREE, 1998., The Textile-Clothing sector in Poland. (French Ambassy, Warsaw).

Duchêne G. And Rusin P., 2002. Small innovative firms in the transition : the Polish case. In Analyses économiques de la transition post-socialiste, Andreff W., (ed), (La Découverte, Paris).

Duchêne G. and Rusin Ph. And Turlea G., 2002. "Entrepreneurship and Institutions in Transition", Journal for Institutional Innovation, Development and Transition, Vol.6.

Feldman M.\& Francis J., 2001. Entrepreneurs and Formation of Industrial Clusters, 3th Conference of Proximity, Paris.

Goldhan G., L'eurorégion “Neisse ”-définition de la partie allemande de l'eurorégion, ronéoté, Hochschule für Technik, Wirtschaft und Sozialwesen, Zittau/Görlitz, 1997.

Grabher G., The Disembedded Regional Economy: The Transformation of East German Industrial Complexes into Western Enclaves, in AMIN\&TRIFT (1994), p177-195.

Gruchman B. \& Glugiewicz E., “ The Role of Innovation in Regional Economic Restructuring in Eastern Europe", in Aydalot \& Keeble, Ed., High Technology Industry and Innovative Environments : The European Experience, Routledge, London-N.York, 1988.

Grudzewski W.M. \& Hejduk I.K. 1998, SMS in Polish market economy, (WSHP, Warsaw).

Henderson W.O. 1954. Britain and Industrial Europe 1750-1870. Studies in British Influence on the Industrial Revolution in Western Europe. ( University Press, Liverpool).

JeanninP., 1991. Dependency and development capacity in Central Europe at the end of "ancien régime", In Cahiers de Varsovie , $\mathrm{N}^{\circ} 22$.

Koza A., 1993. Fondamental problems of textile-clothing Industry in Neisse Euroregion. Master diploma, Economic Academy, Jelenia Gora.

Krätke S., 1997. Regional Integration or Fragmentation? The German-Polish Border Region in a New Europe International Conférence of Regional Sudies Association, 20-23 September, Frankfurt /Oder.

Krugman P.R., "Increasing Returns, Monopolistic Competition and International Trade", in Journal of International Economics, N9/1979.

Kuklinski A., 2002. The Club of Rome. The Future of Europe. The Global Future. A Memorandum. (The Polish Association for the Club of Rome, Warsaw).

Lacquement G., 1993., Rural restructuring in new Länder. In Les Cahiers de l'Obsérvatoire de Berlin, $\mathrm{N}^{\circ} 24$.

Lepesant G., 1997. Development Strategies in cross-border regions of Poland, Germany and Czech Republic. In CERAT Report (University of Grenoble).

Lipowski A. and Despiney B. 1990. Recession and structurals changes in Poland. In Revue des études slaves, $\mathrm{N}^{\circ} 2$.

Maillat D., 1988. « SMS, Innovations and territorial development », In IRER-Cahier, $\mathrm{N}^{\circ} 18$.

Marshall A., Principles of economics, 8e edition, Macmillan, London 1920.

Michalet Ch.-A., 2000. Charming nations or how attract FDI. (Economica, Paris).

Nivet J.F., «Economic restructuring in the new Länder: Light from the East", RECEO, Vol.33. N², 2002.

Pellegrin J., German Production Networks in Central/Eastern Europe. Between Dependency and Globalisation, WZB discussion paper, January, 1999.

Perrin J.C., 1989. Industrial Organisation and territorial aspect. (CER, Aix-en-Provence). Puchala E.(2003), "Human resources management in Polish enterprises in the years 19972001", ROSES Seminar, 25 of November. 
Requier-Desjardins D., 2001., Decentralisation and local productive dynamics in developing countries", Cahiers du GEMDEV (University of Paris 1).

Rogulska B., 1985., Indirect regulation and new relations Centre-enterprise in Poland. In Economie et Société., Cahiers de l'ISMEA, Fasc. G, Nº41.

Samson I and Goutin-Bourlat E. 1995. Openning, transition and development in Germany (CGP, Paris ).

Samson et al., 1996. Poles of growth and decision in the East. 1994-2015. (DATAR, Paris).

Schneider Ch. M., (2000),,Institutional Structure of Research Activities and Transition in Central and Eastern Europe", Thesis, University Paris 1.

Starzyk K., 1996, Cross-Border Co-operation as a Factor of Poland's Integration into the EU. In Polen und die Osterweiterung der Europaischen Union, F.Franzmayer und Ch. Wese (ed.), (Duncker \& Humblot, Berlin

Surdej A., 2001. Small-and Medium-Sized Entreprises Development in Poland after 1990, UNU/WIDER Working Paper, January.

Szlachcicowa I., “ Tozsamosc mieszkancow polsko-niemieckiego pogranicza w Euroregionie Nysa ", Acta Universitatis Wratislaviensis, N²135, 1999.

Veltz P., Mondialisation, villes et territoires. L'économie d'archipel, PUF, Paris, 1996.

Winiecki J, "Formal and Informal Rules in Post-Communist Transition", in Journal of Public Finance and Public Choice, Vol. XVI, N $1,1998$.

WUS, 2001. Euro-regions in the new territorial division of Poland.(WUS editions, Wroclaw).

Zich F., «Problems of Regional Identity in Czek border regions, ronéoté, Technicka Univerzita, Liberec, 1997. 
Figure.1: Basic map of Euro-regions located at the Polish borders.

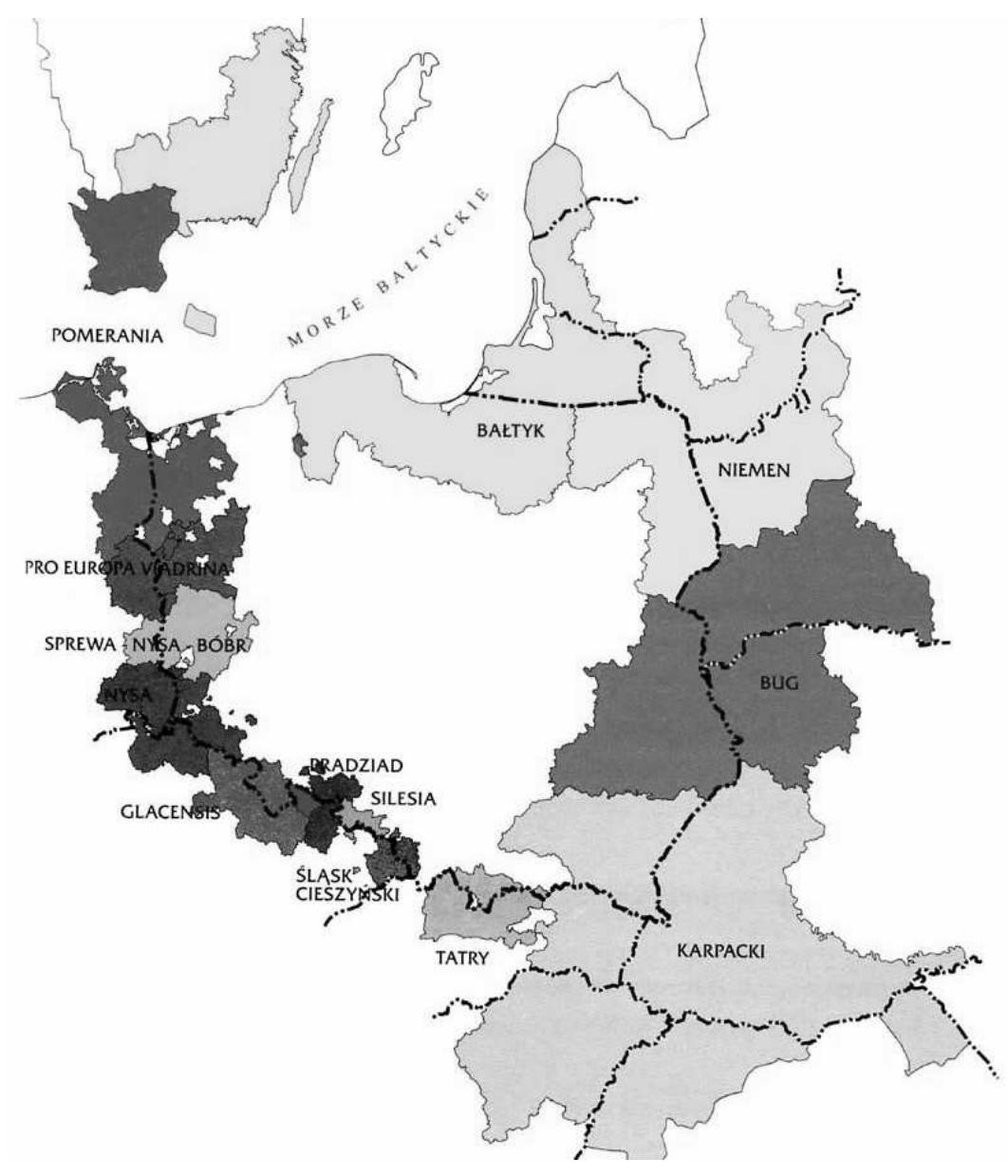

Source: Euroregiony na granicach Polski, US, Wroclaw, 2002. 
Figure 2: "Neisse" Euroregion.

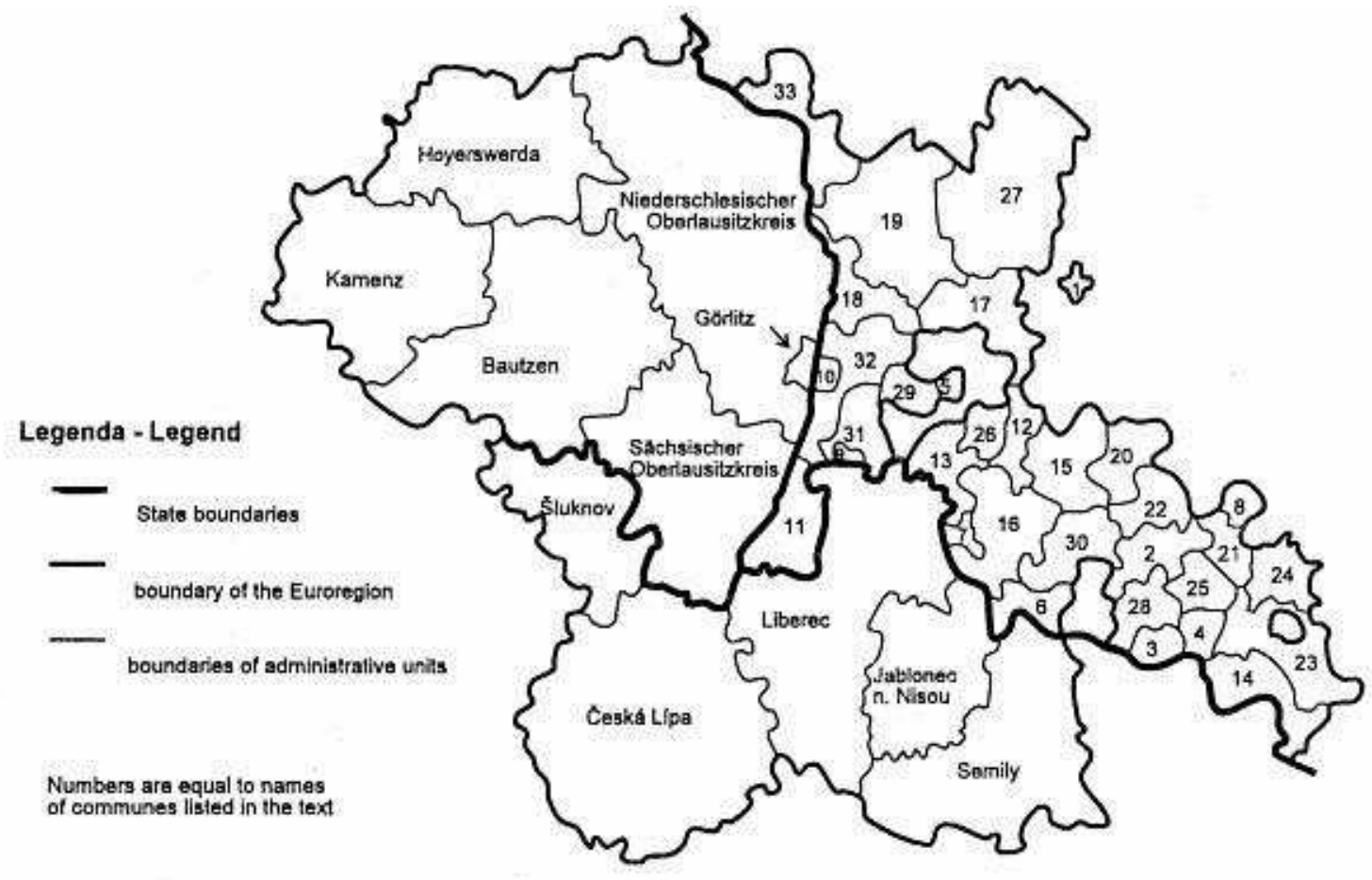

Fig. 5. Administrative division of the Euroregion NEISSE - NISA - NYSA (source: Polish Secretariat of the Euroregion) State for the 1st of August 1994. 
Table 1 : Estimate of the number of active micro-firms 1994-2000 (in thousands and \%):

\begin{tabular}{lccccccc}
\hline & 1994 & 1995 & 1996 & 1997 & 1998 & 1999 & 2000 \\
\hline Micro-firms registered in & 1808 & 1910 & 1986 & 2140 & 2306 & 2904 & 3176 \\
REGON & & & & & & & \\
\hline Of which are active & i 1035 & 1057 & 1255 & 1493 & 1634 & 1744 & 1766 \\
(thousands) and in \% & $57,2 \%$ & $55,3 \%$ & $63,2 \%$ & $69,8 \%$ & $70,9 \%$ & $60,0 \%$ & $55,6 \%$ \\
\hline
\end{tabular}

Source : Duchêne \& Rusin, «Innovation, mobilité du travail et croissance dans la transition. Le « miracle » polonais », ROSES, Paris, 2000 ; Raport o stanie sektora malych i srednich przedsiebiorstw $w$ Polsce $w$ latach 1999-2000, PAED, Warszawa, 2001; Male i srednie przedsiebiorstwa w Polsce 2002, PAED, Warszawa, 2002. 
Table 2: Active SMEs in the Years 1998-2000 by Region (Voivodship/Province).

\begin{tabular}{|c|c|c|c|c|c|c|}
\hline & 1998 & 1999 & 2000 & 1998 & 1999 & 2000 \\
\hline POLAND & & & & 100.0 & 100.0 & 100.0 \\
\hline Mazovia & 281,574 & 261,035 & 285,818 & 16.3 & 14.4 & 16.2 \\
\hline Upper Silesia & 224,938 & 232,349 & 222,035 & 13.1 & 12.8 & 12.6 \\
\hline Great Poland & 155,805 & 179,853 & 179,853 & 9.0 & 9.9 & 9.9 \\
\hline Little Poland & 145,276 & 158,691 & 151,801 & 8.4 & 8.7 & 8.6 \\
\hline Lower Silesia & 127,780 & 148,894 & 139,548 & 7.0 & 8.2 & 7.9 \\
\hline Łódzkie & 126,902 & 132,001 & 121,564 & 7.4 & 7.3 & 6.9 \\
\hline Pomerania & 104,164 & 115,666 & 103,766 & 6.0 & 6.4 & 5.9 \\
\hline Western Pomerania & 89,075 & 100,373 & 95,099 & 5.2 & 5.5 & 5.4 \\
\hline Cujavia-Pomerania & 91,333 & 93,990 & 86,619 & 5.3 & 5.2 & 5.0 \\
\hline Lubelskie & 72,242 & 73,756 & 73,555 & 4.2 & 4.1 & 4.2 \\
\hline Lower Carpathians & 69,860 & 74,211 & 65,310 & 4.1 & 4.1 & 3.7 \\
\hline Warmia -Mazuria & 52,768 & 57,916 & 56,266 & 3.1 & 3.2 & 3.2 \\
\hline Holly Cross & 50,480 & 50,894 & 48,412 & 2.9 & 2.8 & 2.8 \\
\hline Lubuskie & 48,718 & 52,016 & 47,900 & 2.8 & 2.9 & 2.7 \\
\hline Podlasia & 42,167 & 42,432 & 42,526 & 2.4 & 2.3 & 2.4 \\
\hline Opolskie & 40,446 & 41,940 & 41,596 & 2.3 & 2.3 & 2.4 \\
\hline
\end{tabular}

Source: Male I srednie przedsiebiorstwa w Polsce -2002, PARP, Warszawa, 2002. 
Table $N^{\circ} 3$ : Population's dynamic in Görlitz :

\begin{tabular}{|cc|}
\hline Years & Population \\
\hline 1956 & 94000 \\
1970 & 87308 \\
1975 & 83896 \\
1980 & 81399 \\
1985 & 79277 \\
1990 & 72237 \\
1992 & 70172 \\
1995 & 66118 \\
1996 & 64020 \\
\hline
\end{tabular}

Source : Kloberg, 1997. 